\title{
New recommendations for local therapy of knee osteoarthritis and study of ketoprofen efficiency: literature review and results of own researches
}

\section{For citation: Bol', sustavy, pozvonočnik. 2019;9(3):170-177. doi: 10.22141/2224-1507.9.3.2019.178641}

\begin{abstract}
Background. The main complaint of osteoarthritis (OA) patients is a moderate or severe pain, and the drugs most frequently used to reduce it are the non-steroidal anti-inflammatory drugs. Objective: to examine the efficiency and safety of ketoprofen gel used for the treatment of knee OA patients, and also its effect on the severity of pain and improving quality of life. Materials and methods. At the premises of Clinical Physiology and Pathology of the Musculoskeletal System Department of the State Institution "D.F. Chebotarev Institute of Gerontology of the NAMS of Ukraine", we have conducted a pilot study, which included 23 men and women aged 50-69 years with knee osteoarthritis stage 1-2. The patients were divided into two groups: group I - 13 persons whose treatment consisted of applying a thin layer of ketoprofen on the knee joint twice a day for 10 days, and group II - 10 individuals taking placebo (vaseline oil, which didn't contain ketoprofen and active excipients) in the form of knee applications twice a day for 10 days. The study consisted of screening, visit after 10 days of therapy, and visit 20 days after discontinuation of therapy. At each visit, the intensity of pain and functional status of the knee joints were evaluated using the WOMAC scale (total score, subscales of pain, stiffness, daily activity), Lequesne index, and 15-meter test. In addition, a review of the articles from the following electronic medical databases was conducted: PubMed, Google Scholar and the Cochrane Library; there are a large amount of publications based on the effectiveness of different forms and groups of non-steroidal anti-inflammatory drugs and their comparative analysis. Results. In the group of patients who received ketoprofen we have registered: the reduction in the intensity of pain, stiffness, improvement of daily activity according to the WOMAC questionnaire subscales, and decrease of the time of the 15-meter test performance. Conclusions. Thus, ketoprofen was found to be an effective and safe agent for the local therapy of knee OA.
\end{abstract}

Keywords: knee osteoarthritis; ketoprofen; recommendations; review; pain

\section{Introduction}

Osteoarthritis (OA) is the most common cause of articular pain associated with various degrees of functional failure, depreciated life quality; it is also one of the key disability causes in the developed countries, namely among the elderly [5]. The OA is usually characterized by a polyarticular damage, though the most common localization is a knee joint. Across the globe, about $9.6 \%$ of males and $18.0 \%$ of females have a symptomatic knee OA [1]. According to the World Health Organization (WHO)'s prediction, the number of people aged over 65 will increase almost 3 times by 2050 (from $8 \%$ in
2010 to $20 \%$ in 2050), while the number of OA patients will reach 150 million, and 40 million of those won't be able to perform daily tasks [6].

In Ukraine, as in the rest of the world, the OA is more common among women than it is among men: $558.8 \mathrm{fe}-$ male subjects per 100 thousands vs. 423.1 male subjects per 100 thousands [9].

The principal complaint of the OA patients is moderately or acutely pronounced pain [2]. Among the most commonly prescribed medications there are nonsteroidal anti-inflammatory drugs (NSAIDs). They are present at the pharmacological market since the late $19^{\text {th }}$

C) 2019. The Authors. This is an open access article under the terms of the Creative Commons Attribution 4.0 International License, CC BY, which allows others to freely distribute the published article, with the obligatory reference to the authors of original works and original publication in this journal.

Для кореспонденції: Поворознюк Владислав Володимирович, доктор медичних наук, професор, ДУ «Інститут геронтології імені Д.Ф. Чеботарьова НАмН України», вул. Вишгородська, 67, м. Київ, 04114, Україна; e-mail: okfpodac@ukr.net

For correspondence: Vladislav Povoroznyuk, MD, PhD, Professor, State Institution “D.F. Chebotarev Institute of Gerontology of the NAMS of Ukraine”, Vyshgorodska st., 67, Kyiv, 04114, Ukraine; e-mail: okfpodac@ukr.net

Full list of author information is available at the end of the article. 
century, and because of their efficacy retain popularity ever since. However, the idea of certain plants having anti-inflammatory and anesthetic effects dates back to Hippocrates [7]. At the beginning, the people believed in the medicinal qualities of willow's bark and leaves as they contain natural salicylates [9], their counterpart in the modern medicine being acetylsalicylic acid. The Indometacin's analgesic effect was discovered in the early 1960s [8]. The Ketoprofen was synthesized by the French chemists in 1967, and has been used for 50 years $[11,13]$. The Cyclooxygenase (COX) enzyme, discovered in the early 1970 s, is responsible for formation of prostaglandins, prostacyclins and thromboxane A2, from arachidonic acid. The COX discovery resulted in creation of the new NSAID molecules [16]. The late 1990 are associated with the advent of new selective COX-2 inhibitors, coxibs, due to the achieved differentiation of two enzymatic isoforms - COX-1 and COX-2.

Despite the long NSAID history and significant experience of their use, recommendations have been constantly improving. Their principal focus is on safety and avoiding potential side effects. The US Alliance of NSAIDs recommends the lowest possible doses during the shortest possible time, taking into account the health of the patient and individual risk factors [7]. The European League against Rheumatism (EULAR) suggested the local NSAID treatment for the OA in 2013 [20]. The Osteoarthritis Research Society International (OARSI) named local NSAIDs the first-line treatment for the OA in 2008 [20], while the American College of Rheumatology (ACR) made similar recommendations for treating the OA patients over 75 years in 2012 [21].

In 2016, an amended Cochrane Systematic Review "Topical NSAIDs for chronic musculoskeletal pain in adults" was published [19]. A group of authors assessed the efficacy of topical Diclofenac and Ketoprofen, comparing it with the efficacy of topical placebo. The NSAIDs (cream, gel, plaster, spray) have the advantage of minimizing the potential side effects. The lessening of pain occurs at much smaller doses of active ingredient's blood concentration than in case of oral medications [19]. The principal criterion of efficacy for all the studies included into the review was lessening of pain (by about $50 \%$ ) during 6-12 weeks since the treatment starting point. The functional characteristic and pain intensity were evaluated according to the WOMAC, VAS, Likert, Lequesne and the Australian Canadian Osteoarthritis Hand Index (AUSCAN), the latter not being used in Ukraine, as well as according to the patient global evaluation of treatment (PGE).

The 6 assessments of topical Diclofenac use recruited 2343 patients; the clinically successful outcome was achieved in $60 \%$ of main group subjects and $50 \%$ of subjects receiving topical placebo. The duration of treatment was 6-12 weeks. The 4 assessments of topical
Ketoprofen use recruited 2573 patients; the clinically successful outcome was achieved in $63 \%$ of main group subjects, compared to $48 \%$ of subjects receiving topical placebo [19].

The 5 double-blind placebo-controlled studies assessed the efficacy of OA medication according to its form. The Dickson's study compared the efficacy of

$0.5 \%$ Piroxicam gel with the $400 \mathrm{mg}$ Ibuprofen tablets, used 3 times a day during 4 weeks. The topical Piroxicam gel's efficacy was $4 \%$ higher than the tablets. Similar findings were obtained in the Rother's study of 2007 [19]. When the efficacy of $110 \mathrm{mg}$ Ketoprofen gel was compared with the one of $100 \mathrm{mg}$ oral Celecoxib, the incidence of positive outcomes amounted to $46 \%$ (64/138 subjects) for the Ketoprofen group and $39 \%$ (51/132 subjects) for the Celecoxib tablet group (both drugs were used twice a day during 6 weeks).

In most cases, the topical forms turn out more effective than oral ones. However, one study reports a $4 \%$ higher efficacy of $50 \mathrm{mg}$ Diclofenac tablets, used 3 times a day for 12 weeks, than the one of 50 drops of $1.5 \%$ Diclofenac solution, applied topically (Tugwell, 2004). Another assessment of 40 drops of $1.5 \%$ Diclofenac solution, applied 4 times a day, showed a 1 $\%$ higher efficacy than the one of $100 \mathrm{mg}$ Diclofenac tablets per day, taken during 12 weeks (Simon, 2009).

In 2001, Zacher compared the efficacy of the 4-time use of Diclofenac Emulgel (10cm strip) and $300 \mathrm{mg}$ Ibuprofen tablets, taken 3 times a day during 3 weeks. The incidence of positive outcomes amounted to $40 \%$ (66/165 subjects) for the topical NSAID group vs. $34 \%$ (53/156 subjects) for Ibuprofen.

The side effects registered after the topical NSAIDs were characterized as minor, and experienced only by few subjects. The epithelial itching and erythema were more common with topical Diclofenac (20 cases per 100 subjects). The topical use of Ketoprofen and placebo yielded similar results - 5 cases per 100 subjects. When the topical NSAIDs were used by the subjects who also used the per os forms, $17 \%$ and $26 \%$ of those reported side effects of gastrointestinal nature.

In 2019, the amended guidelines on the OA treatment were published by the British National Institute for Health and Care Excellence (NICE). The NICE experts adhere to the holistic approach to the OA treatment. It involves the assessment of treatment's effect on life quality, sleep, daily and professional activities, relations with others, psychoemotional state and leisure activities. The pharmacological treatment involves using the Paracetamol or topical NSAIDs as first-line drugs of choice. If their efficacy is lacking, the oral NSAIDs, COX-2 inhibitors or opioids, in the smallest dose during the shortest possible time, are suggested in combination with the proton-pump inhibitors (PPIs).

At present, the NSAID group includes over 70 agents with various chemical compositions $[10,14,15]$. The Ukrainian market features 28 NSAID pharmacothera- 
peutic groups, with over 400 trade names [10]. According to the WHO, at the moment over $20 \%$ of people in the world are regularly taking the NSAIDs [17]. They are prescribed to the elderly and old people 4 times as often as to the younger ones [18]. Taking into the account the comorbidity and incidence of complications among the subjects of those age groups, it is important to choose the treatment method minimizing the possible side effects.

The purpose. In order to assess the efficacy and safety of Ketoprofen use in gonarthrosis treatment, and to study its effect on the life quality and pain level, we performed a pilot clinical trial at the Department of clinical physiology and pathology of locomotor apparatus, at the State Institution 'D.F. Chebotaryov Institute of gerontology by the NAMS of Ukraine”.

\section{Materials and methods}

The clinical trial had a restricted protocol, being an open, controlled, parallel, randomized, comparative, compliant with the State Pharmacological Center (by the Health Ministry of Ukraine) requirements. All the patients were explained the terms of participation in the trial, they also obtained the "Patient information booklet" they were encouraged to refer to. After gaining all the necessary information, the patients signed the Informed consent (IC) form.

In our study we used $2.5 \%$ Ketoprofen gel with such active additives, as Neroli and Lavandin oil, Carbomer 940, $96 \%$ Ethanol and Triethanolamine (TEA).

The Carbomer 940 is a unique gel medium providing a powerful transdermal transporting of the Ketoprofen to the deepest damaged sites. The Neroli oil has antiseptic, spasmolytic and analgesic properties; it is also one of the most expensive essential oils in the world, extracted from bitter orange. The Neroli oil also has anti-depressive, calming effect. The Lavandin oil has anti-inflammatory and antiseptic properties, with a local anesthetic and calming effect. The Triethanolamine (TEA) is a low-molecular aminospirit, acting as an acid stabilizer and a special oil emulsifier. It dissolves the epithelial fat, provides an optimal $\mathrm{pH}$ and improves the Ketoprofen's penetration.

\section{Characteristics of the examined patients}

The study involved 23 male and female subjects aged 50-69 years, with knee osteoarthritis of the $2^{\text {nd }}$ and $3^{\text {rd }}$ degree. The patients were divided into 2 groups: Group I - 13 patients who were treated with the thin-layered Ketoprofen applications to their knee joints twice a day for 10 days, Group II - 10 patients taking placebo (petroleum jelly without Ketoprofen and active additives) applied to their knee joints twice a day for 10 days. The study included screening, a visit after 10 days of therapy, and after 20 days since the termination of treatment. At the moment of inclusion into the trial, the patients have not been taking any NSAIDs for at least 7 days and/or glucocorticoids - for 4 weeks.

Diagnosis was made according to the patient's complaints (pain and movement limitation of the knee joints, disrupted daily routine), clinical and X-ray data (by J.H. Kellgren \& J.S. Lawrence). An important requirement was signing an Informed consent (IC) form and the patient's compliance.

Those patients who had a known hypersensitivity to the Ketoprofen, its metabolites and/or any other drug component, as well as a history of allergic reaction to the NSAIDs; acute ulcerous disease of stomach or intestine, gastrointestinal hemorrhage or perforation or severe heart failure; hepatic or renal disorders were not included.

\section{Methods}

Clinical examination and functional tests, anthropometric measurements (height, weight, and body mass index) were performed prior to the study, at the $10^{\text {th }}$ day and $30^{\text {th }}$ day. All the patients received the thin-layered applications to their knee joints twice a day for 10 days. From the $11^{\text {th }}$ to $30^{\text {th }}$ day, the drugs were not administered at all.

The pain syndrome dynamics and knee joint functional state were assessed according to the WOMAC scale (general value, sub-scale pain values, pain, rigidity, and daily activity), Lequesne index, and 15-meter test at the beginning of treatment, $10^{\text {th }}$ and $30^{\text {th }}$ day of trial. Intolerance and safety were assessed according to the side effects and reactions, the patients' subjective symptoms and feelings and objective examination findings.

The statistical analysis was performed by means of Statistika 6.0 software. It included the Student's t-test for dependent or independent samples, the Wilcoxon signed-rank test and one-way dispersion analysis (ANOVA). The results are presented as $\mathrm{M} \pm \mathrm{SD}$, and considered significant if $\mathrm{p}<0.05$.

\section{Results}

At the beginning of the study, there were no significant differences between the groups in terms of participants' age, anthropometric data and pain intensity (Table 1).

In the group of patients taking the Ketoprofen, there was a significant lessening of pain syndrome according to the WOMAC pain sub-scale; $41.7 \%$ after 10 days of treatment $(\mathrm{t}=3.81, \mathrm{p}=0.002)$ (Fig. 1$)$. Also by the $10^{\text {th }}$ day of Ketoprofen molecule treatment, there was a significant lessening of rigidity $(\mathrm{t}=3.75, \mathrm{p}=0.003)$, and gonarthrosis-related limitation of daily activity $(\mathrm{t}=4.98$, $\mathrm{p}=0.0003$ ) (Fig. 2, 3). However, at the $20^{\text {th }}$ day of the follow-up observation after the treatment ended, the effect was preserved only partially.

Among the control group patients, there were no significant variations registered in the pain, rigidity 
and daily activity sub-scales at the $10^{\text {th }}$ and $30^{\text {th }}$ day of trial.

There was a significant improvement in a 15-meter test results registered for the Ketoprofen group. At the $10^{\text {th }}$ day of treatment, the average duration of this test performance was $9.3 \pm 2.1$ seconds $(p=0.005)$ and at the $30^{\text {th }}$ day $10.1 \pm 2.1(\mathrm{p}<0.05)$, which was significantly better than the performance at the trial's beginning $10.7 \pm 2.1$ (Fig. 4). No significant variations were registered in the control group.

While comparing the efficacy of treatment in two groups after 10 and 30 days of trial, it was determined that the Ketoprofen significantly improved the pain intensity, rigidity and limitation of daily activity. At the $10^{\text {th }}$ day of Ketoprofen molecule treatment, the patients reported a $41.7 \%$ lessening of pain syndrome, compared with the control group (5.3\%), and this positive dynamics stayed intact by the $30^{\text {th }}$ day of trial in the principal group. Compared with the beginning of treatment, the pain intensity reduced by $17 \%$ in the principal group (Fig. 5).

At the $10^{\text {th }}$ day of Ketoprofen molecule treatment, the rigidity values diminished in the principal group by $35.2 \%(p=0.1)$; however, by the $30^{\text {th }}$ day of trial it increased by $13.9 \%$. In the control group, no variation was registered at the $10^{\text {th }}$ or $30^{\text {th }}$ day of study.

The everyday activity dynamics of patients taking the Ketoprofen was also more pronounced. At the $10^{\text {th }}$ day of treatment, the patients reported a $34 \%$ improvement of everyday activity $(\mathrm{p}<0.001)$, while at the $30^{\text {th }}$ day of

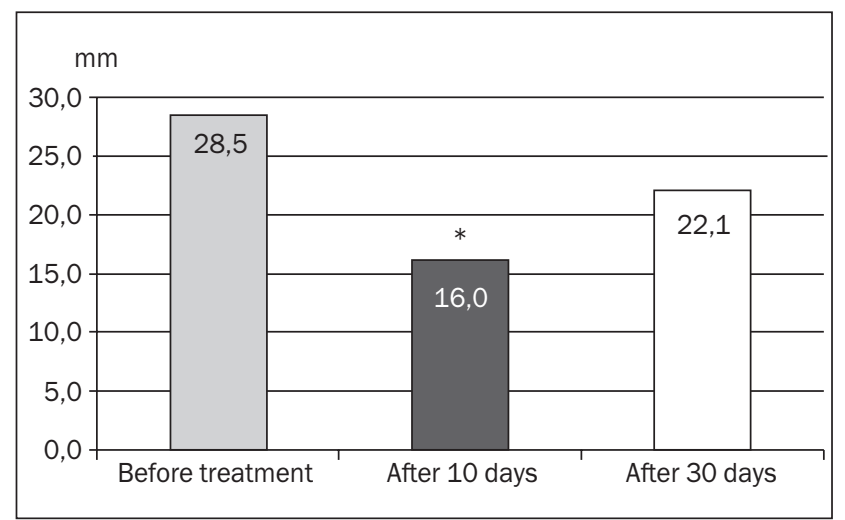

Figure 1. Dynamics of the WOMAC pain sub-scale with the Ketoprofen trial $-11.8 \%$, compared with the results at the beginning of the trial.

The duration of 15-meter test performance reduced significantly in the Ketoprofen group at the $10^{\text {th }}$ day of trial - by $12.9 \%$. There were no significant variations registered in the control group.

The study continues.

\section{Discussion}

The study results prove that the Ketoprofen medication with an active Ketoprofen molecule (gel form) significantly reduces the pain syndrome intensity in the knee OA patients.

According to the reference data, the Ketoprofen molecule has a powerful anti-inflammatory and analgesic effect, and due to its small size and polarization [22], the molecule penetrates deeply into the damaged sites. The Ketoprofen inhibits the prostaglandin and leukotriene synthesis; furthermore, it stabilizes the lysosomal membranes and inhibits the bradykinin activity.

Most studies report the effective diminishing of the pain syndrome when the Ketoprofen is involved. V. Sardana et al. made a systematic review on the topical Ketoprofen efficacy and safety in the knee OA treatment. It was ascertained that the Ketoprofen gel is a more effective tool of the OA treatment than oral medication and topical placebo. Furthermore, the topical form caused fewer side effects compared with the oral NSAID [23]. In 2016, a review on the efficacy of topical

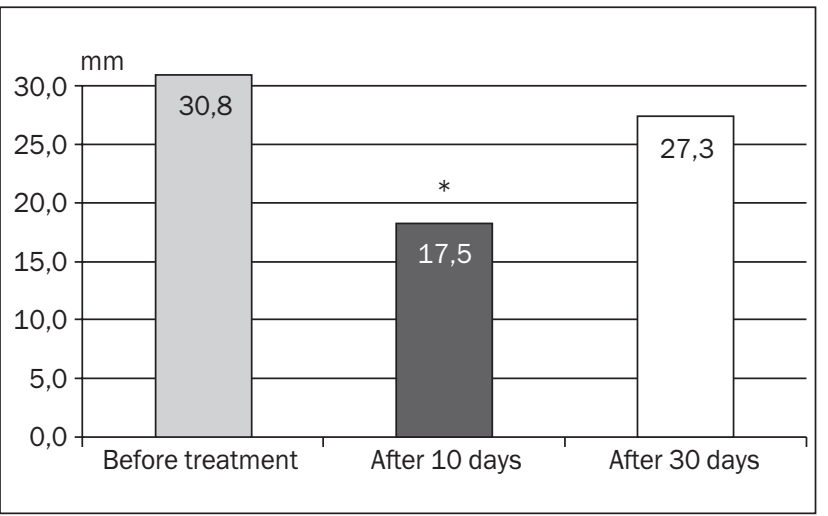

Figure 2. Dynamics of the WOMAC rigidity sub-scale with the Ketoprofen

Note: $*-p<0.05$.

Note: ${ }^{*}-p<0.05$.

Table 1. Characteristics of the examined patients.

\begin{tabular}{|l|c|c|c|c|}
\hline \multicolumn{1}{|c|}{ Parameters } & Group I & Group II & F & p \\
\hline Age, yers & $61,0 \pm 6,8$ & $60,4 \pm 7,9$ & 0,04 & 0,8 \\
\hline Weight, kg & $75,8 \pm 10,8$ & $83,3 \pm 8,6$ & 3,2 & 0,09 \\
\hline Height, cm & $160,4 \pm 8,1$ & $164,7 \pm 7,6$ & 1,7 & 0,2 \\
\hline Body mass index (BMI) & $29,6 \pm 4,9$ & $30,7 \pm 2,4$ & 0,4 & 0,5 \\
\hline
\end{tabular}

Note: Group I - patients treated with the Ketoprofen; Group II - placebo. 


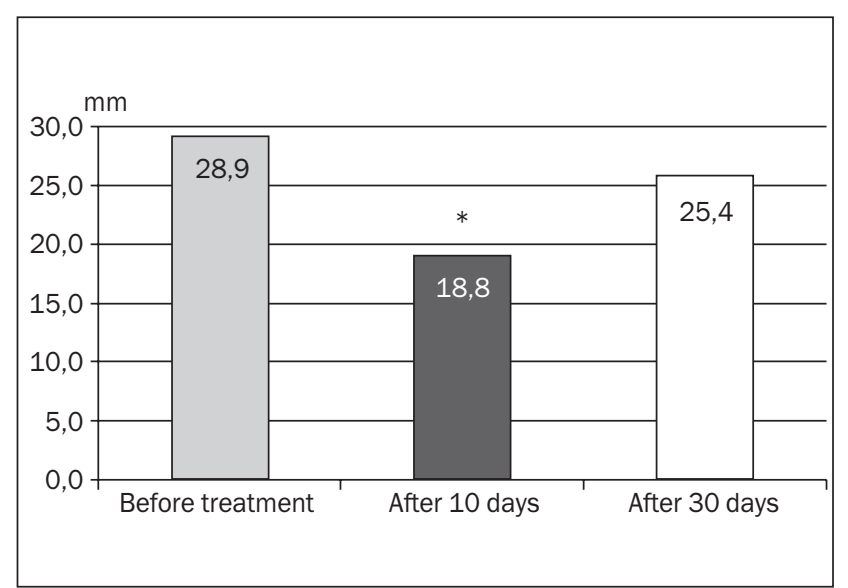

Figure 3. Dynamics of the WOMAC daily activity sub-scale with the Ketoprofen

Note: ${ }^{*}-p<0.05$

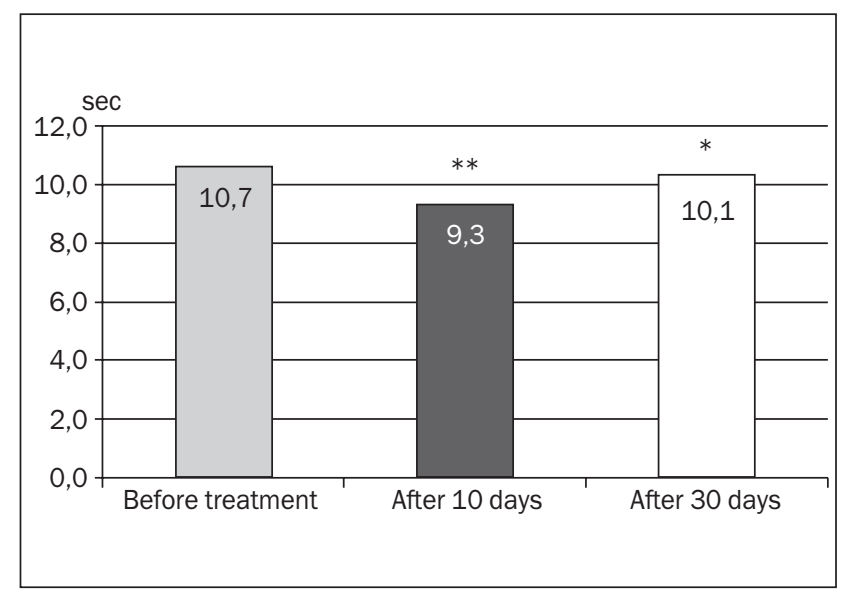

Figure 4. Dynamics of a 15-meter test results with the Ketoprofen

Note: ${ }^{*}-p<0.05, * *-p<0.01$.

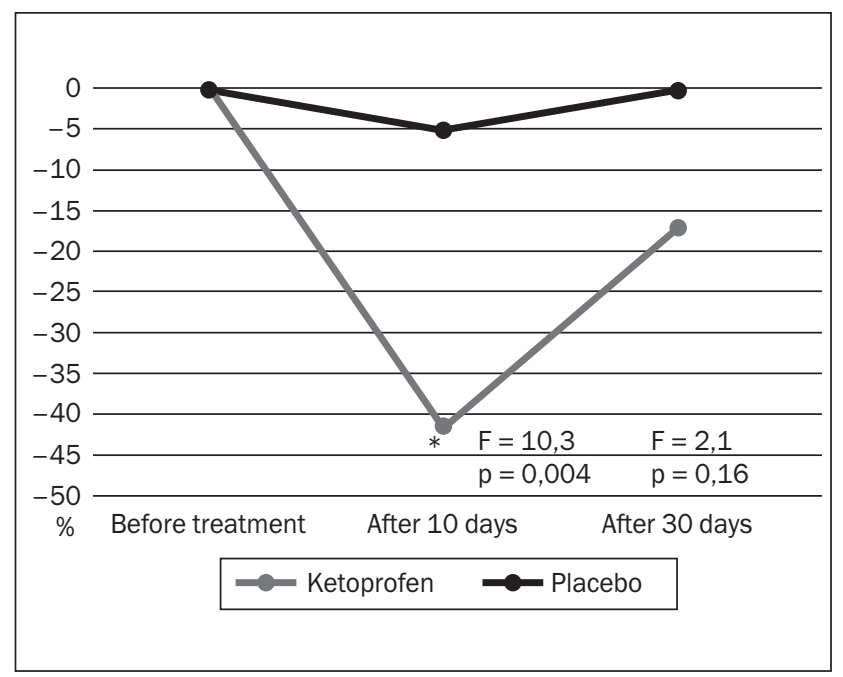

Figure 5. Dynamics of pain intensity compared with the beginning of the Ketoprofen treatment (the WOMAC pain subscale) and the control group

Note: $*$ - $<<0.01$.

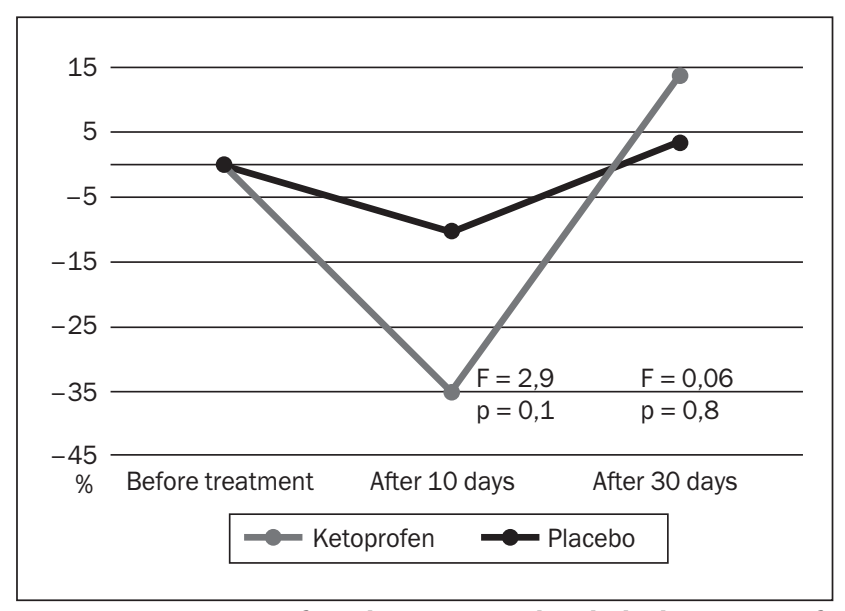

Figure 6. Dynamics of rigidity compared with the beginning of the Ketoprofen treatment (the WOMAC rigidity sub-scale) and the control group

Note: ${ }^{*}-p<0.01$.

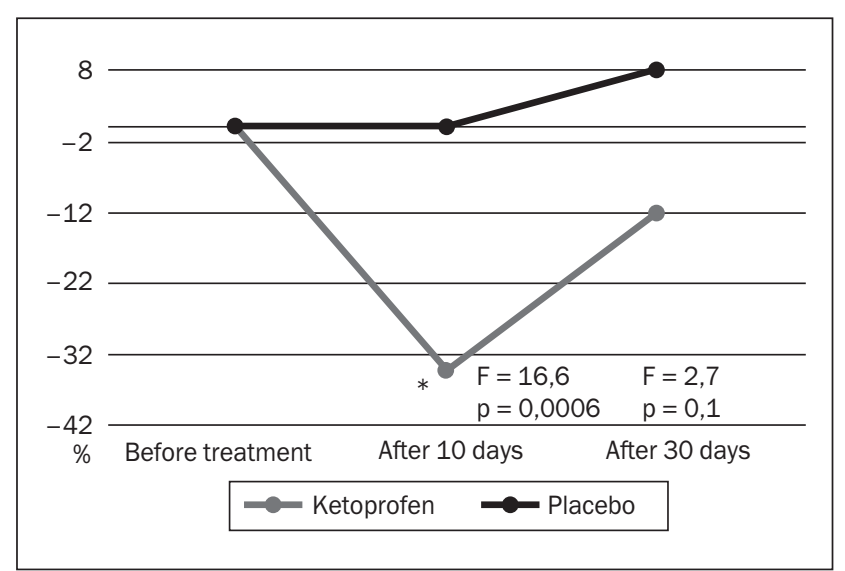

Figure 7. Dynamics of everyday activity compared with the beginning of the Ketoprofen treatment (the WOMAC everyday activity sub-scale) and the control group

Note: $*-p<0.001$.

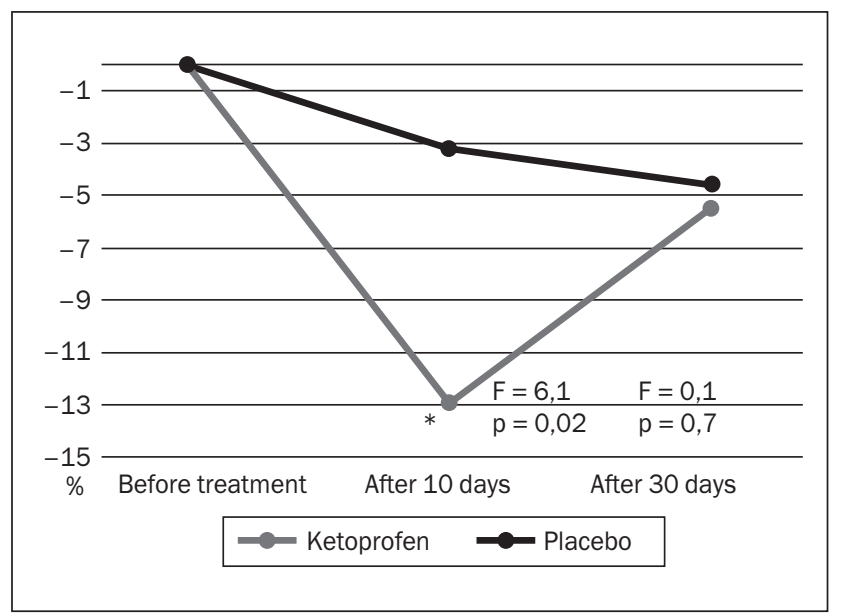

Figure 8. Dynamics of 15-meter test performance compared with the beginning of the Ketoprofen treatment and the control group

Note: $*-p<0.05$. 
NSAIDs for the treatment of chronic musculoskeletal pain in adults it was noted that the Ketoprofen significantly reduced the intensity of OA pain syndrome, unlike the placebo [19].

The reference data of a range of observational and experimental studies deal with the efficacy and safety of topical NSAIDs for various population groups. A metaanalysis examining the topical NSAID effect on the people under 65 , suffering from the sport-induced traumas and acute/chronic musculoskeletal pain, or inflammation arthritis, concludes with a finding that the topical NSAIDs are a safe alternative for the oral ones [24].

In a systemic review and meta-analysis of randomized controlled trials (RCTs) of 2018, the efficacy and safety of the topical NSAIDs were not compromised by any significant gastrointestinal or urinary side effects when the general population was treated for the OA [27]. Chao Zeng et al. consider the topical NSAIDs safer than oral forms in terms of possible comorbidities or other medications being taken. By collecting largescale samples, the researchers managed to dispel the previous RCT findings of more pronounced skin reactions in cases when the topical NSAIDs were used instead of placebo [27].

During the whole period of observation among the Ketoprofen group, no skin reactions were registered.

Another study by F. Rannou et al., also dealing with the OA management issues, compared the efficacy of oral and topical NSAIDs for knee OA treatment, and the latter were found to be safer. Fewer side effects were attributed to the topical NSAID diminished systemic absorption compared to the oral ones. As a result, the topical NSAIDs better corresponded with safety and efficacy of the elderly patients' treatment, especially for those who had comorbidities, increased risk of cardiovascular, gastrointestinal or renal side effects. Furthermore, with the inflammatory rheumatic diseases, the topical NSAID use reduced the need for anti-inflammatory oral medications by $40 \%[24,26]$.

\section{Conclusions}

To sum up the reference and our study data, the Ketoprofen gel is an effective and safe tool of the knee OArelated pain syndrome treatment.

The NICE, EULAR, OARSI, ACR clinical guidelines emphasize the topical NSAID preference as the first-line medication, especially in the elderly patients. Using the topical NSAIDs to treat the chronic locomotor apparatus diseases is a commonplace recommendation, as they are able to reduce the pain syndrome's intensity without any associated systemic adverse effects. The Ketoprofen gel significantly reduces pain and improves everyday activity of patients. No side effects were registered during the trial.

Conflicts of interests. Authors declare the absence of any conflicts of interests and their own financial in- terest that might be construed to influence the results or interpretation of their manuscript.

\section{References}

1. Valdes AM, Stocks J. Osteoarthritis and ageing. EMJ.2018;3(1):116-123.

2. Geenen R, Overman CL, Christensen R, et al. EULAR recommendations for the health professional's approach to pain management in inflammatory arthritis and osteoarthritis. Ann Rheum Dis. 2018 Jun;77(6):797-807. https://doi.org/10.1136/annrheumdis-2017-212662.

3. Mishchenko OYa, Bereznyakov AV. Nonsteroidal anti-inflammatory drugs for topical use: analysis of evidence of effectiveness in the treatment of muscle-joint pain. In: Proceeding of the I International Scientific and Practical Conference on Current problems of pharmacotherapy and prescription of medicines: Medications to humans. Vol 1. 2017, March 3031; Kharkiv, Ukraine. Kharkiv: NUPh; 2017. 204-209 pp. (in Ukrainian).

4. Stanos S. Osteoarthritis Guidelines: A Progressive Role for Topical NSAIDs. J Multidiscip Healthc. 2013;6:133-137. https://dx.doi. org/10.2147\%2FJMDH.S35229.

5. Nüesch E, Dieppe P, Reichenbach S, Williams $\mathrm{S}$, Iff $\mathrm{S}$, Jüni $\mathrm{P}$. All cause and disease specific mortality in patients with knee or hip osteoarthritis: population based cohort study. BMJ. 2011 Mar 8;342:d1165. https://doi.org/10.1136/bmj.d1165.

6. World Health Organization(WHO); US National Institute of Aging. Global health and ageing. Available from: https://www.who.int/ageing/publications/ global health/en/. Accessed: October 1, 2011.

7. Alliance for Rational Use of NSAIDs. Nonsteroidal anti-inflammatory drugs (NSAIDs): what you need to know. Available from: https://nsaidalliance. com/what-you-need-to-know/.

8. Rao P, Knaus EE. Evolution of nonsteroidal anti-inflammatory drugs (NSAIDs): cyclooxygenase (COX) inhibition and beyond. J Pharm Pharm Sci. 2008 Sep 20;11(2):81s-110s.

9. Osteoarthrosis. In: Babak OJa, editor. Semejnyj vrach. Terapevt. Racional'naja diagnostika i farmakoterapija zabolevanij vnutrennih organov. Tom 1. [Family doctor. Therapist. Rational diagnosis and pharmacotherapy of diseases of internal organs. Vol 1]. Kyiv: Zdorov`ja Ukrai'ny; 2017. Available from: http://www.dovidnyk.org/dir/12/58/759.html. (in Russian).

10. Kostjuk VG. Naukove obg'runtuvannja social'no-ekonomichnyh pryncypiv upravlinnja tovarnoju politykoju vyrobnychyh farmacevtychnyh pidpryjemstv. Diss. kand. farm. nauk [Scientific substantiation of the socio-economic principles of managing the product policy of manufacturing pharmaceutical 
enterprises. PhD diss.]. Kharkiv; 2018. 27-56 pp. (in Ukrainian).

11. Karateev AE. Ketoprofen in the treatment of acute and chronic pain: a review. Available from: https://www.lvrach.ru/2014/07/15436007/. Accessed: August 28, 2014. (in Russian).

12. Kotvitska AA, Kostiuk VH. Research of normative legal regulation of import substitution production of medicines in Ukraine. Management, Economics and Quality Assurance in Pharmacy. 2016;45(1):44-48. https://doi.org/10.24959/uekj.16.6. (in Ukrainian).

13. Rother M, Lavins BJ, Kneer W, Lehnhardt K, Seidel EJ, Mazgareanu S. Efficacy and safety of epicutaneous ketoprofen in Transfersome (IDEA-033) versus oral celecoxib and placebo in osteoarthritis of the knee: multicentre randomised controlled trial. Ann Rheum Dis. 2007 Sep;66(9):1178-83. https://doi. org/10.1136/ard.2006.065128.

14. Dzjak GV, Stepanov JuM, Grycenko VI, Kushnirenko IV. A modern view of gastropathy caused by non-steroidal anti-inflammatory drugs. Celecoxib and the state of the secretory function of the stomach. Modern Gastroenterology. 2003;11(1):4-10. (in Ukrainian).

15. Maljuta LJa. Strategichne upravlinnja innovacijnym rozvytkom pidpryjemstva : navchal'nyj posibnyk [Strategic management of innovative development of an enterprise: a manual]. Ternopil: FOP Paljanycja VA; 2016. 232 p. (in Ukrainian).

16. El-Bogdadi D. The Untold NSAID Story. Available from: https://arapc.com/nsaid-story/.

17. Svintsitskyy AS. Mechanisms of therapeutic efficacy and adverse reaction of non-steroidal antiinflammatory drugs. Praktikuucij likar. 2012;(4):5-12. (in Ukrainian).

18. Shatylo VB, Stadnjuk LA, Asanov EO, Pryhod'ko VJu. Features of the use of non-steroidal anti-inflammatory drugs in the elderly. Mystectvo likuvannja. 2010;68(2):13-19. (in Ukrainian).

19. Derry S, Conaghan P, Da Silva JA, Wiffen PJ, Moore RA. TopicalNSAIDs for chronic musculoskeletal pain in adults. Cochrane Database Syst Rev. 2016 Apr 22;4:CD007400. https://doi. org/10.1002/14651858.CD007400.pub3.

20. Balmaceda CM. Evolving guidelines in the use of topical nonsteroidal anti-inflammatory drugs in the treatment of osteoarthritis. BMC Musculoskelet Dis- ord. 2014 Jan 21;15:27. https://doi.org/10.1186/14712474-15-27.

21. Hochberg MC, Altman RD, April KT, et al. American College of Rheumatology 2012 recommendations for the use of nonpharmacologic and pharmacologic therapies in osteoarthritis of the hand, hip, and knee. Arthritis Care Res (Hoboken). 2012 Apr;64(4):465-74. https://doi.org/10.1002/ acr.21596.

22. Komatsu T, Sakurada T. Comparison of the efficacy and skin permeability NSAID preparations used in Europe. Eur J Pharm Sci. 2012 Dec 18;47(5):8905. https://doi.org/10.1016/j.ejps.2012.08.016.

23. Sardana V, Burzynski J, Zalzal P. Safety and efficacy of topical ketoprofen in transfersome gel in knee osteoarthritis: A systematic review. Musculoskeletal Care. 2017 Jun;15(2):114-121. https://doi. org $/ 10.1002 / \mathrm{msc} .1163$.

24. Makris UE, Kohler MJ, Fraenkel L. Adverse effects of topical nonsteroidal antiinflammatory drugs in older adults with osteoarthritis: a systematic literature review. J Rheumatol. 2010 Jun;37(6):1236-43. https://doi.org/10.3899/jrheum.090935.

25. Mason L, Moore RA, Edwards JE, Derry S, McQuay HJ. Topical NSAIDs for acute pain: a metaanalysis. BMC Fam Pract. 2004 May 17;5:10. https:// doi.org/10.1186/1471-2296-5-10.

26. Rannou F, Pelletier JP, Martel-Pelletier J. Efficacy and safety of topical NSAIDs in the management of osteoarthritis: Evidence from real-life setting trials and surveys. Semin Arthritis Rheum. 2016 Feb;45(4 Suppl):S18-21. https://doi.org/10.1016/j. semarthrit.2015.11.007.

27. Zeng C, Wei J, Monica S, et al. Relative efficacy and safety of topical non-steroidal anti-inflammatory drugs for osteoarthritis: a systematic review and network meta-analysis of randomised controlled trials and observational studies. Br J Sports Med. 2018 May;52(10):642-650. https://doi.org/10.1136/ bjsports-2017-098043.

Received 11.06.2019

Revised 24.06.2019

Accepted 10.07.2019

\section{Information about authors}

V.V. Povoroznyuk, MD, PhD, Professor, Head of the Department of clinical physiology and pathology of locomotor apparatus, State Institution "D.F. Chebotarev Institute of Gerontology of the NAMS of Ukraine", Kyiv, Ukraine, e-mail: okfpodac@ukr.net, ORCID iD: http://orcid.org/0000-0002-9770-4113

A.S. Musiienko, PhD, Junior Research Fellow at the Department of clinical physiology and pathology of locomotor apparatus, State Institution "D.F. Chebotarev Institute of Gerontology of the NAMS of Ukraine", Kyiv, Ukraine

N.V. Hryb, PhD, Junior Research Fellow at the Department of clinical physiology and pathology of locomotor apparatus, State Institution "D.F. Chebotarev Institute of Gerontology of the NAMS of Ukraine", Kyiv, Ukraine

A.A. Tkachuk, PhD, Laboratory assistant I category at the Department of clinical physiology and pathology of locomotor apparatus, State Institution "D.F. Chebotarev Institute of Gerontology of the NAMS of Ukraine", Kyiv, Ukraine 
Поворознюк В.В., Мусієнко А.С., Гриб Н.В., Ткачук А.А.

ДУ «Інститут геронтології імені Д.Ф. Чеботарьова НАМН України», Український науково-медичний центр проблем остеопорозу, м. Київ, Україна

\section{Нові рекомендації з локальної терапії остеоартрозу колінних суглобів та дослідження ефективності кетопрофену: огляд літератури й результати власних досліджень}

Резюме. Актуальність. Основною скаргою пацієнтів 3 остеоартрозом (ОА) є біль помірної або значної інтенсивності, а найбільш часто вживаними засобами, що використовують для зменшення больового синдрому, - нестероїдні протизапальні препарати (НПЗП). Мета: вивчення ефективності та безпечності терапії препаратом кетопрофен у формі геля, що використовували для лікування хворих з гонартрозом, а також його впливу на вираженість больового синдрому та якість життя. Mamepiaлu ma мето$\partial u$. На базі відділу клінічної фізіології та патології опорнорухового апарату ДУ «Інститут геронтології ім. Д.Ф. Чеботарьова НАМН України» проведене пілотне дослідження, в якому взяли участь 23 особи чоловічої та жіночої статі віком 50-69 років з остеоартрозом колінних суглобів III стадії. Пацієнти були поділені на дві групи: група I - 13 пацієнтів, лікування яких полягало у нанесенні препарату кетопрофен у вигляді аплікацій тонким шаром на колінний суглоб двічі на добу протягом 10 днів, і група II - 10 пацієнтів, які приймали плацебо (вазелінова олія, що не містила у своєму складі кетопрофен та активні допоміжні речовини) у вигляді аплікацій на колінний суглоб двічі на до- бу протягом 10 днів. Дослідження складалось із скринінгу, візиту через 10 днів терапії та візиту через 20 днів після припинення прийому терапії. При кожному візиті проводили оцінку інтенсивності больового синдрому та функціонального стану колінних суглобів, що визначали за допомогою шкали WOMAC (загальний показник, показники субшкал болю, скутості, повсякденної активності), індексу Лекена та 15-метрового тесту. Крім того, проведено огляд статей електронних медичних баз даних PubMed, Google Scholar та Cochrane Library, у якому надані велика кількість публікацій щодо ефективності різних форм та представників групи НПЗП і їх порівняльний аналіз. Результати. У групі пацієнтів, які приймали препарат кетопрофен, зареєстроване вірогідне зменшення інтенсивності больового синдрому, проявів скутості, поліпшення повсякденної активності за даними субшкал опитувальника WOMAC та зменшення часу виконання 15 -метрового тесту. Висновки. Кетопрофен є ефективним та безпечним засобом локальної терапії при лікуванні ОА колінних суглобів.

Ключові слова: остеоартроз колінних суглобів; кетопрофен; рекомендації; огляд; біль

Поворознюк В.В., Мусиенко А.С., Гриб Н.В., Ткачук А.А.

ГУ «Институт геронтологии имени Д.Ф. Чеботарева НАМН Украины», Украинский научно-медицинский центр

проблем остеопороза, г. Киев, Украина

\section{Новые рекомендации по локальной терапии остеоартроза коленных суставов и исследования эффективности кетопрофена: обзор литературы и результаты собственных исследований}

Резюме. Актуальность. Основной жалобой пациентов с остеоартрозом (ОА) является боль умеренной или значительной интенсивности, а наиболее часто применяемыми препаратами, которые используются для уменьшения болевого синдрома, - нестероидные противовоспалительные препараты (НПВП). Цель исследования: изучение эффективности и безопасности терапии препаратом кетопрофен в форме геля, который использовали для лечения больных с остеоартрозом коленных суставов I-II степени, а также его влияния на выраженность болевого синдрома и качество жизни. Материалы и методы. На базе отдела клинической физиологии и патологии опорно-двигательного аппарата ГУ «Институт геронтологии им. Д.Ф. Чеботарева НАМН Украины» проведено пилотное исследование, в котором приняли участие 23 человека мужского и женского пола в возрасте 50-69 лет с остеоартрозом коленных суставов I-II степени. Пациенты были разделены на две группы: группа I - 13 пациентов, лечение которых состояло в нанесении кетопрофена в виде аппликаций тонким слоем на коленный сустав 2 раза в день в течение 10 дней, и группа II - 10 пациентов, принимавших плацебо (вазелиновое масло, не содержащее в своем составе кетопрофен и активные вспомогательные вещества) в виде апплика- ций на коленный сустав 2 раза в день в течение 10 дней. Исследование состояло из скрининга, визита через 10 дней терапии и визита через 20 дней после прекращения приема терапии. На каждом визите проводили оценку интенсивности болевого синдрома и функционального состояния коленных суставов с помощью шкалы WOMAC (общий показатель, показатели субшкал боли, скованности, повседневной активности), индекса Лекена и 15-метрового теста. Кроме того, проведен обзор статей электронных медицинских баз данных PubMed, Google Scholar и Cochrane Library, где представлены большое количество публикаций об эффективности различных форм и представителей группы НПВП и их сравнительный анализ. Результаты. В группе пациентов, принимавших препарат кетопрофен, зарегистрировано достоверное уменьшение интенсивности болевого синдрома, проявлений скованности, улучшение повседневной активности по данным субшкал опросника WOMAC и уменьшение времени выполнения 15-метрового теста. Выводы. Кетопрофен является эффективным и безопасным средством локальной терапии при лечении ОА коленных суставов.

Ключевые слова: остеоартроз коленных суставов; кетопрофен; рекомендации; обзор; боль 